\title{
Redescription of Gymnorhynchus isuri (Cestoda: Trypanorhyncha) from Isurus oxyrinchus (Elasmobranchii: Lamnidae)
}

\author{
Marcelo Knoff ${ }^{1}$, Sérgio Carmona de São Clemente ${ }^{2}$, Roberto Magalhães Pinto ${ }^{1}$, Reinalda Mariza Lanfredi ${ }^{3}$ \\ and Delir Corrêa Gomes ${ }^{1}$
}
${ }^{1}$ Laboratório de Helmintos Parasitos de Vertebrados, Departamento de Helmintologia, Instituto Oswaldo Cruz - Fiocruz, Avenida Brasil 4365, 21045-900, Rio de Janeiro, RJ, Brazil;
${ }^{2}$ Laboratório de Inspeção e Tecnologia de Alimentos, Faculdade de Veterinária, Universidade Federal Fluminense, Rua Vital Brazil 64, 24230-340, Niterói, RJ, Brazil;
${ }^{3}$ Laboratório de Biologia de Helmintos Otto Wucherer, Instituto de Biofísica Carlos Chagas Filho, Universidade Federal do Rio de Janeiro, 21949-900, Rio de Janeiro, RJ, Brazil

\begin{abstract}
Key words: Cestoda, Trypanorhyncha, Gymnorhynchus isuri, Elasmobranchii, Isurus oxyrinchus, Santa Catarina, Brazil
\end{abstract}

\begin{abstract}
Specimens of the elasmobranch, Isurus oxyrinchus Rafinesque, captured in 1999 in the state of Santa Catarina, Brazil, were parasitized with the poecilacanthoid trypanorhynch cestode Gymnorhynchus isuri Robinson, 1959, that is redescribed here. New details of scolex and proglottid morphology are given. These details are mainly related to tentacle armature, terminal genitalia and observations of external morphology of proglottids.
\end{abstract}

During a parasitological helminth survey, specimens were recovered from 90 elasmobranchs off the southern coast of Brazil. Recently data on some of the parasites have been reported for nematodes (Knoff et al. 2001a), digeneans and acanthocephalans (Knoff et al. 2001b), and trypanorhynch cestodes (Knoff et al. 2002, 2004a, b, c, Gomes et al. 2005, Pinto et al. 2006). The present study is related to Gymnorhynchus isuri Robinson, 1959 (Eucestoda, Trypanorhyncha) recovered from the spiral valve of Isurus oxyrinchus Rafinesque (Lamnidae), collected off the coast of Santa Catarina.

This trypanorhynch cestode was originally described on the basis of adult specimens recovered in the spiral valve of the mako shark, I. oxyrinchus $[=$ Isurus glaucus (Müller et Henle)], from Makara, Cook Strait, New Zealand by Robinson (1959) and re-studied by Caira and Bardos (1996) based on cestodes recovered from specimens of I. oxyrinchus captured in Mountauk, Long Island, New York, USA.

The present paper adds new morphological data on the species, in order to elucidate some important details and to improve the knowledge of G. isuri.

\section{MATERIALS AND METHODS}

In March 1999, four females of Isurus oxyrinchus, 165$221 \mathrm{~cm}$ of total length, were captured about 190 miles off the coast of the State of Santa Catarina $\left(27^{\circ} 08^{\prime} \mathrm{S}-28^{\circ} 38^{\prime} \mathrm{S}\right.$; $\left.45^{\circ} 30^{\prime} \mathrm{W}-46^{\circ} 53^{\prime} \mathrm{W}\right), 25 \mathrm{~m}$ depth, by professional fishermen of the Kiyomã tuna fishing vessel. On board, spiral valves, were collected, labeled and cooled on ice before examination. Cestodes were recovered, fixed, stained and mounted according to the technique of Amato et al. (1991). Taxonomic classification is in accordance with Campbell and Beveridge (1994). Measurements and terminology follow Dollfus (1942), Campbell and Beveridge (1994), Jones et al. (2004) and Palm (2004). Measurements are in millimetres $(\mathrm{mm})$ unless otherwise indicated; means are followed by range in parentheses. In the taxonomic summaries, the total of parasitized specimens and the infrapopulation of each host are indicated. NGR refers to New Geographical Record; drawings were made with the aid of a drawing tube connected to a brightfield Olympus BH2 microscope (BM). One specimen was routinely prepared and was analyzed under a JEOL scanning electron microscope (SEM). To differentiate ventral from dorsal tentacles in adult worms a practical procedure was adopted to prepare specimens for SEM studies: under a stereomicroscope before the preparation for stubbing, the tentacles should not be detached from the scolex and the observation of the first immature proglottids together with the scolex will indicate the proper position, since the ventral region of the proglottid is naturally concave. Representative specimens were deposited in the Coleção Helmintológica do Instituto Oswaldo Cruz, (CHIOC), Rio de Janeiro, Brazil; samples for comparison were also obtained from the Museum of New Zealand (Te Papa Tongarewa) Parasite Collection, Wellington, New Zealand (MNZ); United States National Parasite Collection, Beltsville, USA (USNPC). At least one host specimen of the investigated fish species was deposited as symbiotype sensu Brooks (1993), in the collection of the Instituto de Pesca, Santos, SP, Brazil (IP) and listed by Knoff et al. (2001b). 


\section{RESULTS}

Poecilacanthoidea Dollfus, 1942

Gymnorhynchidae Dollfus, 1935

Gymnorhynchus Rudolphi, 1819

\section{Gymnorhynchus isuri Robinson, 1959}

Figs. 1-21

Description based on 2 adults, 1 mounted and measured, and 1 utilized for SEM studies. Scolex long, cylindrical, acraspedote, 9.00 long, 1.80 wide. Greatest width, 3.2, in bothrial region. Bothrial and post-bothrial surfaces regions devoid of microtriches. Pars bothrialis with four auriculate elongate bothria, with rounded edges, in two separate pairs on opposite faces of scolex, linked by velum, concave faces turned towards each other, 2.84 long, 3.2 wide in lateral view. Pars vaginalis with sinuous sheaths, 3.84 (allowing for bulbar displacement) or 4.80 (not allowing for bulbar displacement) long. Pars bulbosa 3.24 (not allowing for bulbar displacement) or 4.20 (allowing for bulbar displacement) long, 1.62 wide, in lateral view retractor muscle deeply inserted in bulbar cavity. Bulbs, 3.02-3.24 long, 0.68-0.76 wide. Pars post-bulbosa 0.96 long. Tentacles arising from anterior bothrial margins, partially extroverted, proximal region cylindrical, unarmed, with plicate or telescopic-like shape, 1.60-3.02 long, 0.26-0.28 wide. Distinctive basal armature with corona of long falciform hooks with rounded extremities. Corona of long falciform hooks around base of tentacles with pattern of glide reflection symmetry consisting in halfspiral rows of hooks, ascending from internal to external face. Hooks of corona hollow (BM) with pores (SEM). Tentacles 1 and 2 have one large central hook (1C) and 7 hooks in each half-spiral row: 2(2'), 3(3'), 4(4'), $5\left(5^{\prime}\right), 6\left(6^{\prime}\right) 7\left(7^{\prime}\right)$ and $8\left(8^{\prime}\right)$. Tentacles 3 and 4 have 8 hooks in each half-spiral row: 1(1'), 2(2'), 3(3'), 4(4'), $5\left(5^{\prime}\right), 6\left(6^{\prime}\right) 7\left(7^{\prime}\right)$ and $8\left(8^{\prime}\right)$. Hooks 1C / 1(1'), 2(2'), $3\left(3^{\prime}\right), 4\left(4^{\prime}\right), 5\left(5^{\prime}\right)$, are large, hook 2(2') largest; 5(5') and 7(7') median; 6(6') and 8(8') smallest. Hooks $1 \mathrm{C}$ (central, on tentacles 1 and 2 ) and $1\left(1^{\prime}\right)$ (on tentacles 3 and 4), 2(2'), 3(3'), 4(4') $0.144 \times 0.036-0.230 \times 0.054$ (length $\times$ width), 5(5') and 7(7') $0.072 \times 0.022-0.112 \times$ 0.025 (length $\times$ width), 6(6') and $8\left(8^{\prime}\right) 0.022 \times 0.007-$ $0.040 \times 0.011$ (length $\times$ width). Metabasal armature poecilacanthous, hooks hollow, in half-spiral rows of hooks, ascending, from internal to external face, longest hooks in middle of row, with 9 hooks each, separated by a double chainette. Hooks $1\left(1^{\prime}\right), 0.036-0.084$ long, $0.016-$ 0.060 wide, hooks 2 (2') $0.048-0.160$ long, $0.020-0.068$ wide, hooks 3(3') 0.056-0.188 long, 0.012-0.068 wide, hooks 4(4') 0.060-0.196 long, 0.016-0.076 wide, hooks 5(5') 0.064-0.196 long, 0.020-0.076 wide, hooks 6(6') 0.040-0.192 long, 0.012-0.068 wide. Hooks 7(7')$9\left(9^{\prime}\right)$, pointed, spiniform, becoming smaller in size; hooks 7(7') 0.036-0.168 long, 0.012-0.040 wide, hooks 8(8') 0.032-0.124 long, 0.012-0.040 wide, hooks 9(9') 0.028-0.076 long, 0.008-0.028 wide. Four singlewinged double chainettes on external face between each principal hook row. Chainette hooks 0.022-0.036 long, 0.016-0.050 wide. First elements of chainette, from $1 \mathrm{st}$ to 7 th row, similar to principal row hooks, 0.012-0.024 long, 0.006-0.012 wide. Strobila hyperapolytic, about $20 \mathrm{~cm}$ long. Proglottids wide, at first wider than long, increasing gradually in size. Genital pore marginal, irregularly alternating and pre-equatorial; ventral and a dorsal elliptical structures, with 7 to 8 folds adjacent to genital pore as well as numerous papillae. Mature proglottids wider than long, acraspedote. Gravid proglottids with a few eggs, 1.70-1.84 long, 4.19-4.66 wide, with eggs occupying more than half of proglottid, 2.94-3.60 long, 4.78-4.80 wide. Testes numerous, more than 1,000 in number, pre-ovarian, irregular in shape, distributed throughout proglottid, 0.064-0.088 in diameter. External seminal vesicle and accessory seminal vesicle present. Cirrus pouch oval, 0.48-0.50 long, $0.24-0.26$ wide, with internal seminal vesicle. Ovary in posterior third of proglottid, tetralobate, bilobate in dorso-ventral view, each lobe $0.26-0.28$ wide. Mehlis' gland well defined, in ovarian isthmus. Vagina tubular, sinuous, extending from ovarian isthmus to level of cirrus pouch, entering genital atrium, latero-ventrally to cirrus pouch. Uterus tubular, median, extending from middle to anterior extremity of proglottid, deviated porally in immature and mature segments, at level of mid-line of accessory seminal vesicle, saccular, with about 11 branches in gravid proglottids. Uterine pore present. Vitelline follicles circumcortical, interrupted by ovary. Paired osmoregulatory canals. Collapsed eggs 48-52 $\mu \mathrm{m}$ long, 24-32 $\mu \mathrm{m}$ wide.

$\mathrm{Host} / \mathrm{site}$ of infection:2(1;1) specimens from spiral valve of 2 females of $I$. oxyrinchus (NGR).

L o c a 1 i t y : Coast of the State of Santa Catarina.

S pecimen deposited: CHIOC no. 34513 a-b.

$\mathrm{M}$ a t e r i a 1 e x a m i n e d: Adults, from Isurus oxyrinchus (=I. glaucus), Cook Strait, New Zealand (MNZ no. 198 be, holotype); from I. oxyrinchus, Mountauk, Long Island, New York, USA (USNPC no. 85936-85939 / M1670-15, 21-25).

Remarks. The morphology of the two adult specimens collected from I. oxyrinchus in Santa Catarina agrees with the description of $G$. isuri based on adults recovered from the spiral valve of the mako shark $I s u$ rus oxyrinchus (=I. glaucus), from Makara, Cook Strait, New Zealand by Robinson (1959). Palm (2004) reported that the type host of $G$. isuri was Prionace glauca (Linnaeus, 1758), but Robinson (1959) reported "I. glaucus (Müller et Henle)" as the type host and not "I. glaucus Linnaeus, 1758"; the latter was synonymized with Prionace glauca. Caira and Bardos (1996) added new data to the original description of $G$. isuri, particularly features of the mature proglottids, based on specimens recovered from I. oxyrinchus captured in Mountauk, Long Island, Nova York, USA. Both the holotype of $G$. isuri and the material from the USA were examined for comparison and differences between the descriptions 

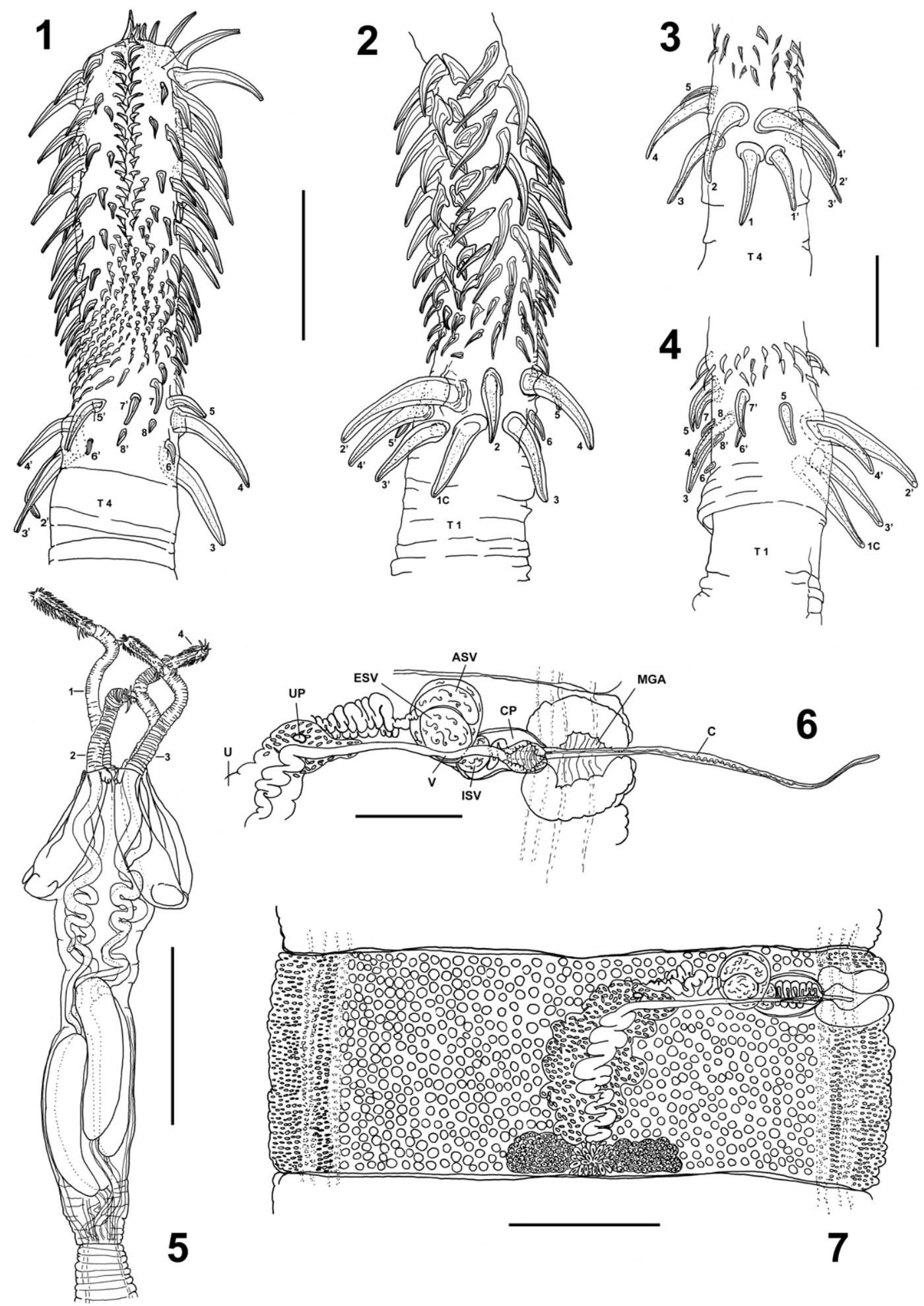

Figs. 1-7. Gymnorhynchus isuri. Fig. 1. Tentacle 4, with the set of four single-winged double chainettes on the external face. Fig. 2. Tentacle 1, basal armature, corona of long hooks, with hook 1 central (1C), internal face. Fig. 3. Tentacle 4, basal armature, corona of long hooks, with hooks 1(1'), internal face. Fig. 4. Same tentacle as in Fig. 2, external face. Fig. 5. Scolex. Fig. 6. Detail of the terminal genitalia, ventral view. Uterine pore (UP) present on the anterior extremity of the uterus (U). Vagina (V), latero-ventral to the cirrus pouch (CP), and muscular genital atrium (MGA). External seminal vesicle (ESV), accessory seminal vesicle (ASV) and cirrus pouch with internal seminal vesicle (ISV). Everted cirrus (C). Fig. 7. Gravid proglottid: uterus with a few eggs, ventral view. Scale bars: Fig. $1=3.0 \mathrm{~mm}$; Figs. 2, $5=0.2 \mathrm{~mm}$; Figs. 3, $4=0.25 \mathrm{~mm}$; Fig. $6=0.5$ mm; Fig. $7=1.0$ $\mathrm{mm}$. 

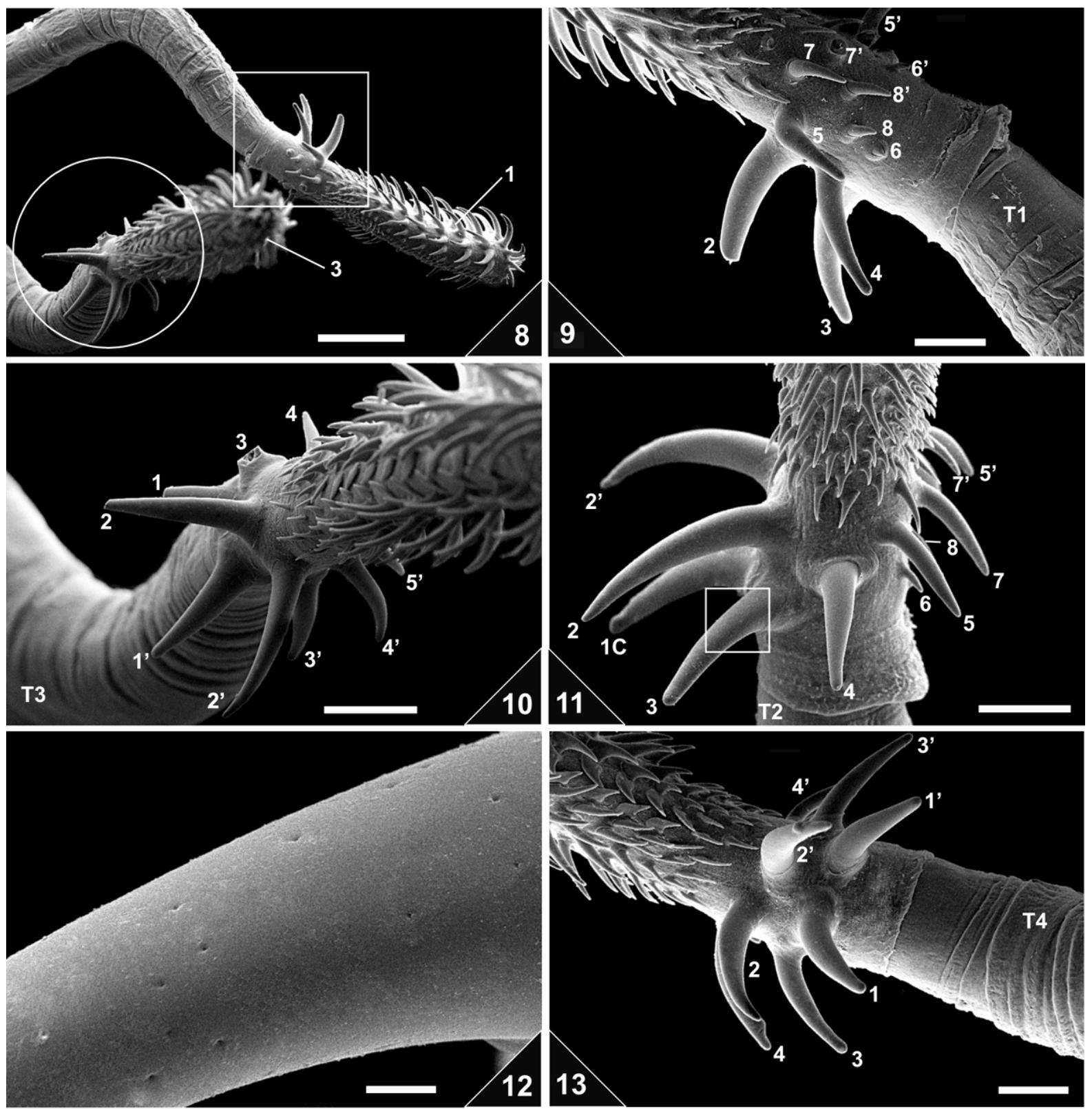

Figs. 8-13. Gymnorhynchus isuri, by SEM. Fig. 8. Tentacles 1 and 2. Square and circle indicate regions from which Figs. 9 and 10, were obtained, respectively. Fig. 9. Tentacle 1, basal armature, corona of long hooks, antibothrial face. Fig. 10. Tentacle 3, basal armature, corona of long hooks, with hooks 1(1'), internal face. Fig. 11. Tentacle 2, basal armature, corona of long hooks, with hook 1 central (1C), antibothrial face. Square indicates the region from which Fig. 12 was obtained. Fig. 12. Detail of pores from one hook of the corona. Fig. 13. Tentacle 4, basal armature, corona of long hooks, with hooks 1(1'), internal face. Scale bars: Fig. $8=300 \mu \mathrm{m}$; Fig. $9=80 \mu \mathrm{m}$; Figs. $10=40 \mu \mathrm{m}$; Figs. $11,13=90 \mu \mathrm{m}$; Fig. $12=9 \mu \mathrm{m}$.

of Robinson (1959) and Caira and Bardos (1996) were analyzed. Robinson (1959, p. 388) referred to the basal tentacular armature as: “...the basal armature consists of a ring of from 13 to 15 hooks of widely varying size. The smallest hooks are situated on the external surface of the proboscide...". His drawings (figs. 24-25, p. 387) of these hooks of the basal corona of the tentacle, show 13 hooks, with hook 1 central and half-turns of six additional hooks, the first four the largest, $5\left(5^{\prime}\right)$ and $7\left(7^{\prime}\right)$ of medium size and $6\left(6^{\prime}\right)$ the smallest. Nevertheless, the original figures of Robinson (1959) do not show the tentacles of the opposite face. During examination of the holotype (MNZ no. $198 \mathrm{~b}-\mathrm{e}$ ), it was possible to observe the presence of only three tentacles that were preserved in two whole mounts; another slide contained the scolex without tentacles. On the slide with the tentacle that was the basis for the illustration of the basal corona in the original description and which re- 

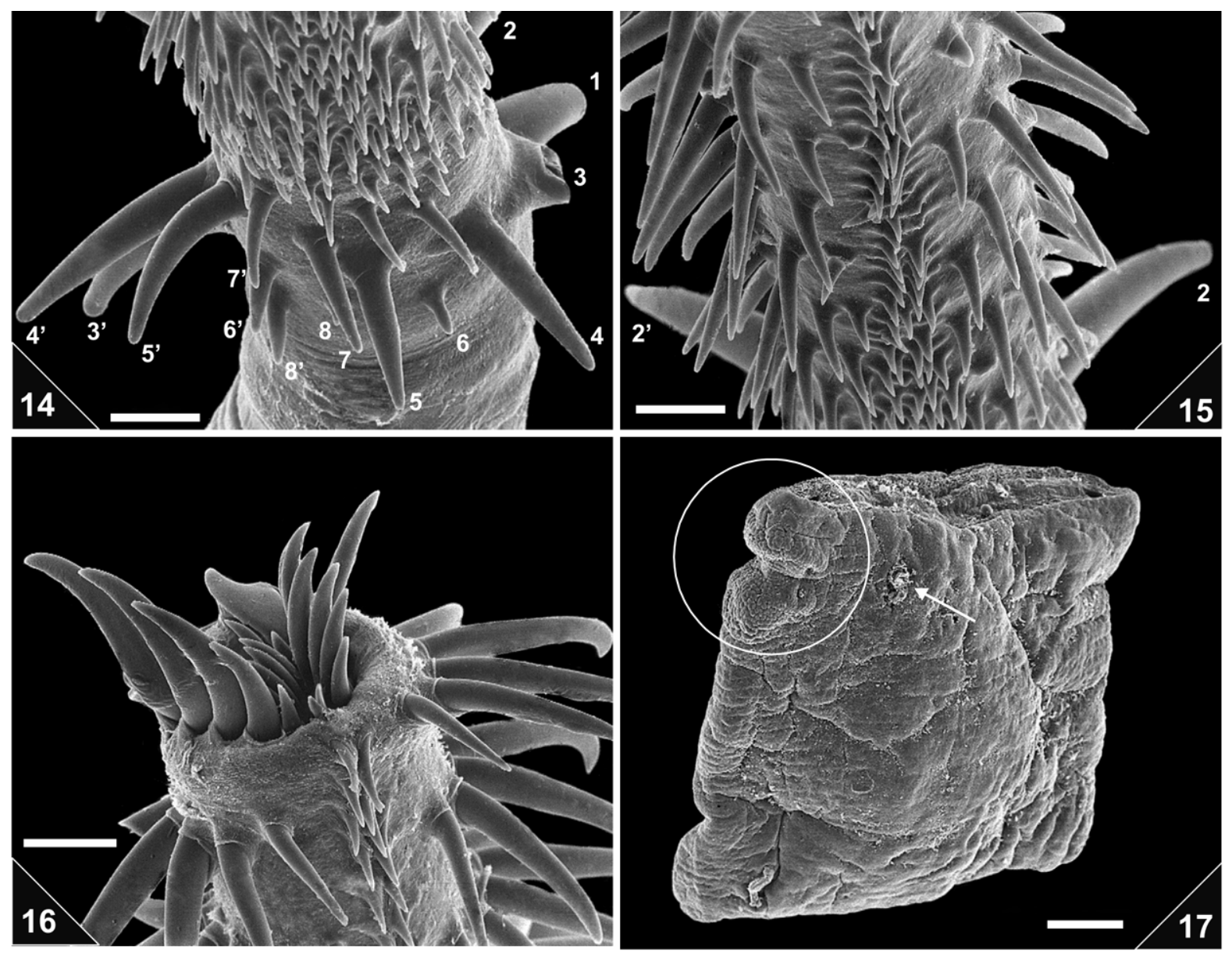

Figs. 14-17. Gymnorhynchus isuri, by SEM. Fig. 14. Tentacle 3, basal armature, external face. Fig. 15. Tentacle 3, metabasal armature, double chainettes composed of four sets of single-winged pairs of hooks, external face. Fig. 16. Tentacle 3, apical metabasal armature, not completely everted, external face. Fig. 17. Proglottid, ventral view. Genital pore. Arrow indicates the uterine pore. Circle indicates the region from which Fig. 18 was obtained. Scale bars: Figs. $14-16=50 \mu \mathrm{m}$; Fig. $17=500 \mu \mathrm{m}$.

ferred to the large central hook (1C), the unarmed portion of the tentacle is damaged: the damage extends beyond the corona region, where, possibly, the smaller hooks $8\left(8^{\prime}\right)$ might have been present. On the other slide, with two additional tentacles, despite the same bad conditions, the coronae of the basal hooks present the double hooks 1(1') with the other hooks following the same pattern observed in the Brazilian specimens, including the presence of the last three small hooks $6\left(6^{\prime}\right)$ to $8\left(8^{\prime}\right)$. Due to the separation of tentacles from the scolex, it was impossible to determine their orientation. Based on these observations, new data are added to the description of Robinson (1959), namely that in the corona of the two tentacles, there are 16 hooks rather than 15. It is possible that, in the tentacle referred to as possessing 13 hooks, the last two hooks may have been overlooked. Caira and Bardos (1996) reported that the specimens collected from Mountauk represented the same species, as they possessed the same number of large hooks in the tentacular basal armature. Following examination of the borrowed material, it was confirmed that the specimens of G. isuri recovered from I. oxyrinchus in the USA, deposited in the USNPC, showed the same pattern of hooks in the basal corona as the Brazilian specimens.

One of the characters utilized by Robinson (1959), to distinguish the species, was the length of the unarmed tentacular region. However, this feature, varies greatly, not only due to the eversion of the tentacles, but also due to contraction of the basal unarmed region. In the specimens preserved as whole mounts, collected off the coast of the State of Santa Catarina, the tentacular unarmed region was $1.60-3.20 \mathrm{~mm}$ long, differing from the New Zealand specimens of G. isuri $(0.60 \mathrm{~mm}$ long) and from those from the USA $(0.34-1.53 \mathrm{~mm}$ long) (measurements from borrowed specimen USNPC 86936/M1670-15). Nevertheless, in the Brazilian specimen, examined by SEM, one of the four tentacles exhibited a reduced length of the basal unarmed region, suggesting that this character may not to be reliable for specific diagnosis as has been suggested by Palm (2004). 

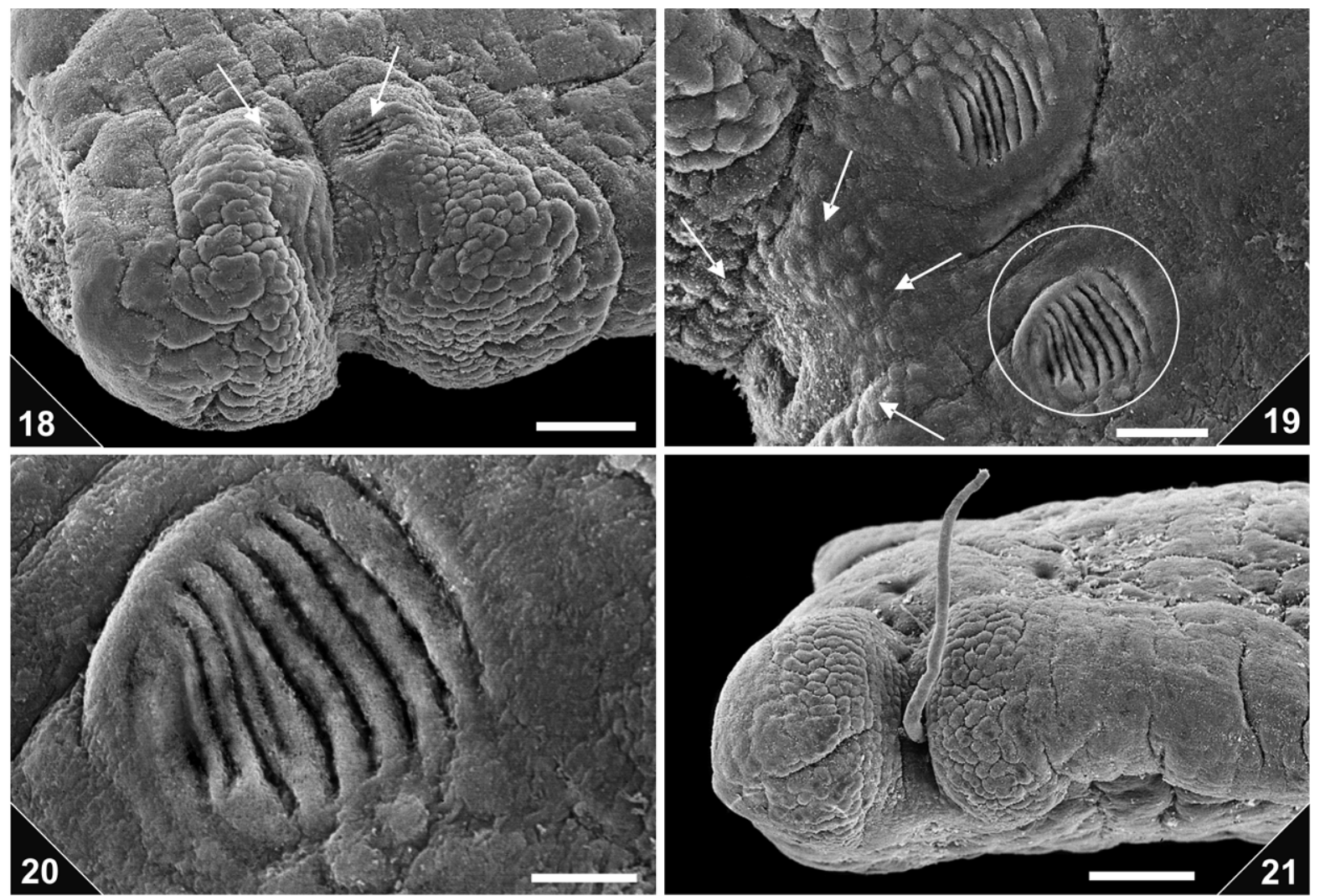

Figs. 18-21. Gymnorhynchus isuri, by SEM. Fig. 18. Region around the genital pore with corrugations and numerous papillae, latero-ventral view. Pair of elliptical structures next to the genital pore indicated by arrows. Fig. 19. Detail of region around genital pore, papillae indicated by arrows, ventral view. Circle indicates the region from which Fig. 20 was obtained. Fig. 20. Detail of the elliptical structure, next to the genital pore. Fig. 21. Genital pore, with everted cirrus, lateral view. Scale bars: Fig. $18=100 \mu \mathrm{m}$; Fig. $19=50 \mu \mathrm{m}$; Fig. $20=20 \mu \mathrm{m}$; Fig. $21=200 \mu \mathrm{m}$.

In the proglottids of the Brazilian specimens, it was possible to observe external seminal vesicle (ESV), accessory seminal vesicle (ASV), differing from what was reported by Caira and Bardos (1996) and Palm (2004) that referred to ASV as absent. Moreover, Caira and Bardos (1996) observed a retracted cirrus projecting into external seminal vesicle, in disagreement with the present results, showing that when the cirrus was not everted, the retraction only occurred inside the cirrus pouch. Besides, according to Palm (2004) the presence of the internal seminal vesicle is confirmed. In addition a uterine pore was observed using SEM, a character not reported in previous descriptions; in the material from the USNPC, the uterine pore appeared inconspicuous under $\mathrm{BM}$.

The lack of microtriches on several regions of the scolex is in agreement with the observations of Caira and Bardos (1996), who only detected densely packed, slender, filiform microtriches on distal bothrial surfaces. Their absence was considered uncommon by these authors, since this pattern had been regarded by Richmond and Caira (1991) as a synapomorphy for the Trypanorhyncha. Nevertheless, these authors examined the scoleces from three collections to ensure that this result was not an artifact of fixation or specimen treatment.
They also suggested that since G. isuri is a large cestode other similarly sized cestodes should be examined to see whether the absence of microtriches is correlated with size. Since the function of microtriches is poorly understood, it is possible that one or more of their functions may not be required by a large worm. Studies using SEM and TEM (Transmission Electron Microscopy) of plerocerci of Gymnorhynchus gigas Cuvier, 1817, collected from the musculature of specimens of Brama raii [=Brama brama (Bonnaterre)] from the Straits of Gibraltar, Spain by Casado et al. (1999a, b) identified four different types of sensorial receptors, but only revealed filiform microtriches associated with the receptors in the pars bothrialis, pars post-bothrialis, pars bulbosa and pars post-bulbosa.

In the Brazilian specimens, numerous papillae were observed around the genital pore, and a ventral and a dorsal pair of elliptical structures, with 7 to 8 folds, were also observed next to the genital pore, representing novel observations. These structures are not conspicuous under BM but were well defined using SEM. In this study, the papillae around the genital pore were observed in whole mounts from mako sharks from New Zealand (holotype) and from the USA. The pair of elliptical muscular structures was evident in some of the 
proglottids of specimens collected from the USA, but they were not evident in those available from New Zealand.

The comparison of the additional characters observed here in G. isuri with Molicola horridus (Goodsir, 1841) as re-described by Knoff et al. (2004b), notes the presence of genital papillae around the genital pore in both species, but the fact that the two species differ in the presence of ventral and dorsal elliptical structures with 7 to 8 folds next to the genital pore in $G$. isuri. The pattern of distribution of the hooks of the tentacular basal corona of these two species, in which tentacles 1 and 2 are identical with a central hook (1C), and the tentacles 3 and 4 are identical with hook 1(1') double, are similar but they differ in the total number of hooks. Specimens of $G$. isuri possess 15 and 16 hooks while $M$. horridus possess 13 and 14 hooks, on tentacles 1 and 2, and 3 and 4 , respectively. The differences between these two species relate to the external surface of the tentacles (band of hooks in M. horridus, and a chainette in G. isuri) and reinforce the previous analysis of Beveridge et al. (1999). These authors suggested that the transition among the typical heteroacanthous and atypical heteroacanthous or poecilacanthous trypanorhynchs, evolved from a common ancestor, due to the similar structures of the strobila and further developed into several lineages based on differences observed in the tentacular armature.

Acknowledgements. To Dr. Eric P. Hoberg, Curator of USNPC, Beltsville, USA for the loan of voucher specimens, Dr. Ricardo Palma, Curator of MNZ, Wellington, New Zealand, for the loan of holotype of G. isuri, Mrs. Heloisa M.N. Diniz, Mr. Rodrigo Mexas and Mr. Bruno E. da Silveira from the Laboratório de Produção e Processamento de Imagem Científica do IOC, FIOCRUZ, for figure processing, Dr. Alberto F. Amorim and Carlos A. Arfelli, from the IP, Santos, Brazil, for the identification of the fishes, the crew of the Kiyomã tuna fishing vessel from Santos for the help during the capture of the hosts, Conselho Nacional de Desenvolvimento Científico e Tecnológico - $\mathrm{CNPq}$ and Fundação Amparo à Pesquisa do Estado do Rio de Janeiro - FAPERJ, for partial financial support.

\section{REFERENCES}

Amato J.F.R., Boeger W.A., Amato S.B. 1991: Protocolos para Laboratório - Coleta e Processamento de Parasitos de Pescado. Imprensa Universitária, Universidade Federal Rural do Rio de Janeiro, Seropédica, 81 pp.

Beveridge I., CAMPBell R.A., PAlm H.W. 1999: Preliminary cladistic analysis of genera of the cestode order Trypanorhyncha Diesing, 1863. Syst. Parasitol. 42: 29-49.

BROOKS D.R. 1993: Extending the symbiotype concept to host voucher specimens. J. Parasitol. 79: 631-633.

CAIRA J.N., BARDOS T. 1996: Further information on Gymnorhynchus isuri (Trypanorhyncha: Gymnorhynchidae) from the shortfin mako shark. J. Helminthol. Soc. Wash. 63: 188192.

CAMPBELl R.A., BEVERIDGE I. 1994: Order Trypanorhyncha Diesing, 1863. In: L.F. Khalil, R.A. Bray and A. Jones (Eds.), Keys to the Cestode Parasites of Vertebrates. CAB International, Wallingford, pp. 51-148.

CASAdO N., MORENO M.J., URREA-PARIS M.A., RODRIGUEZCAABEIRO F. 1999a: Ultrastructural study of the papillae and presumed sensory receptors in the scolex of the Gymnorhynchus gigas plerocercoid (Cestoda: Trypanorhyncha). Parasitol. Res. 85: 964-973.

CASAdo N., Moreno M.J., URREA M.A., RodrigueZ-CAABEIRO F. 1999b: Tegumental topography of the plerocercoid of Gymnorhynchus gigas (Cestoda: Trypanorhyncha). Parasitol. Res. 85: 124-130.

DOLlFus R.P. 1942: Études critiques sur les tetrarhynques du Muséum de Paris. Arch. Mus. Natl. Hist. Nat. Paris 19: 1466

Gomes D.C., KNOFF M., SÃo Clemente S.C., LANFredi R.M., PINTO R.M. 2005: Taxonomic reports of Homeacanthoidea (Eucestoda: Trypanorhyncha) in Lamnid and Sphyrnid elasmobranchs collected off the coast of Santa Catarina, Brazil. Parasite 12: 15-22.

Jones M.K., CAMPBell R.A., BeVeridge I., PAlm H.W. 2004 Terminology of sucker-like organs of the scolex of trypanorhynch cestodes. Syst. Parasitol. 59: 121-126.
Knoff M., SÃo Clemente S.C., Pinto R.M., Gomes D.C. 2001a: Nematodes of elasmobranch fishes from the southern coast of Brazil. Mem. Inst. Oswaldo Cruz 96: 81-87.

Knoff M., SÃo Clemente S.C., Pinto R.M., Gomes D.C. 2001b: Digenea and Acanthocephala of elasmobranch fishes from the southern coast of Brazil. Mem. Inst. Oswaldo Cruz 96: 1095-1101.

KnOfF M., SÃo Clemente S.C., PINTO R.M., GOMES D.C. 2002: Prevalência e intensidade de infecção de cestóides Trypanorhyncha de elasmobrânquios nos estados do Paraná e Santa Catarina, Brasil. Parasitol. Latinoam. 57: 149-157.

Knoff M., SÃo Clemente S.C., Pinto R.M., Gomes D.C. 2004a: Registros taxonômicos de cestóides Trypanorhyncha/Homeacanthoidea em elasmobrânquios coletados na costa do Estado do Paraná, Brasil. Parasitol. Latinoam. 59: 31-36.

Knoff M., SÃo Clemente S.C., PINTO R.M., LANFredi R.M., GOMES D.C. 2004b: Taxonomic reports of Otobothrioidea (Eucestoda, Trypanorhyncha) from elasmobranch fishes of the southern coast off Brazil. Mem. Inst. Oswaldo Cruz 99: 31-36.

Knoff M., SÃo Clemente S.C., Pinto R.M., LANFREdi R.M., GOMES D.C. 2004c: New records and expanded descriptions of Tentacularia coryphaenae and Hepatoxylon trichiuri homeacanth trypanorhynchs (Eucestoda) from carcharhinid sharks from the State of Santa Catarina off-shore, Brazil. Brazil. J. Vet. Parasitol. 13: 73-80.

PALM H.W. 2004: The Trypanorhyncha Diesing, 1863. PKSPLIPB Press, Bogor, $\mathrm{x}+710 \mathrm{pp}$.

PinTo R.M., KNOFF M., SÃo Clemente S.C., LANFredi R.M., GOMES D.C. 2006: The taxonomy of some Poecilacanthoidea (Eucestoda: Trypanorhyncha) from elasmobranchs off the southern coast of Brazil. J. Helminthol. 80: 291-298.

RICHMOND C., CAIRA J.N. 1991: Morphological investigation into Floriceps minacanthus (Trypanorhyncha: Lacistorhynchidae) with analysis of the systematic utility of scolex microtriches. Syst. Parasitol. 19: 25-32.

ROBINSON E.S. 1959: Some new cestodes from New Zealand marine fishes. Trans. R. Soc. N. Z. 86: 381-392. 